University of Wollongong

Research Online

Faculty of Engineering - Papers (Archive)

Faculty of Engineering and Information

Sciences

June 2004

\title{
Characterization of Nanocrystalline Si-MCMB Composite Anode Materials
}

G. X. Wang

University of Wollongong, gwang@uow.edu.au

J. Yao

University of Wollongong, jyao@uow.edu.au

Hua-Kun Liu

University of Wollongong, hua@uow.edu.au

Follow this and additional works at: https://ro.uow.edu.au/engpapers

Part of the Engineering Commons

https://ro.uow.edu.au/engpapers/139

\section{Recommended Citation}

Wang, G. X.; Yao, J.; and Liu, Hua-Kun: Characterization of Nanocrystalline Si-MCMB Composite Anode Materials 2004.

https://ro.uow.edu.au/engpapers/139

Research Online is the open access institutional repository for the University of Wollongong. For further information contact the UOW Library: research-pubs@uow.edu.au 


\title{
Characterization of Nanocrystalline Si-MCMB Composite Anode Materials
}

\author{
G. X. Wang, ${ }^{\mathrm{Z}}$ Jane Yao, and H. K. Liu*
}

Institute for Superconducting and Electronic Materials, University of Wollongong, New South Wales 2522, Australia

Nanocrystalline Si-mesocarbon microbeads (MCMB) composite anode materials were prepared by ballmilling. Scanning electron microscopic observation showed that the spherical shape of MCMB particles can be retained via moderate ballmilling. Ballmilling conditions have an impact on the capacity and cyclability of nanocrystalline Si-MCMB composites. The optimized Si-MCMB composite anode demonstrated a reversible capacity of $1066 \mathrm{mAh} / \mathrm{g}$ with good cyclability. A reaction model has been proposed to explain the reaction mechanisms of lithium insertion and extraction in the Si-MCMB electrode.

(c) 2004 The Electrochemical Society. [DOI: 10.1149/1.1764411] All rights reserved.

Manuscript submitted November 3, 2003; revised manuscript received December 21, 2003. Available electronically June $14,2004$.

Various types of carbonaceous materials such as natural and synthetic graphites, cokes, carbon and graphite fibers, pyrolysis carbons, and mesocarbon microbeads (MCMB), have been widely used as anode materials for lithium-ion batteries. ${ }^{1-3}$ Carbon anodes have a theoretical lithium intercalation capacity of $372 \mathrm{mAh} / \mathrm{g}$ to form $\mathrm{LiC}_{6}$ intercalation compound. Among them, mesocarbon microbeads (MCMB) represent an industry benchmark as anode materials for lithium-ion batteries, which deliver a reversible capacity of 300-340 $\mathrm{mAh} / \mathrm{g}$ and excellent cyclability. Recently, various tin-based lithium storage alloys and tin oxide composites have attracted intensive investigation worldwide. The formation of $\mathrm{Li}_{4.4} \mathrm{Sn}$ results in a theoretical capacity of $991 \mathrm{mAh} / \mathrm{g}$ for element Sn. However, this alloying process is accompanied by a $259 \%$ volume increase, causing severe disintegration of the electrode (cracking and crumbling). ${ }^{4,5}$ This problem can be partly alleviated by using intermetallic tin alloys $\left(\mathrm{M}_{x} \mathrm{Sn}\right)$ such as $\mathrm{Cu}_{6} \mathrm{Sn}_{5},{ }^{6,7} \mathrm{SnMnC},{ }^{8} \mathrm{FeSn}_{2}, \mathrm{FeSn},{ }^{9-11} \mathrm{Ni}_{3} \mathrm{Sn}_{4},{ }^{12}$ and tin-based amorphous composite oxides (TCO). ${ }^{13,14}$ When $\mathrm{M}_{x} \mathrm{Sn}$ alloys react with lithium, $\mathrm{Li}_{x} \mathrm{Sn}$ alloys are formed. The inactive $\mathrm{M}$ matrixes are generated simultaneously, which are usually nanosize in nature and can buffer the volume increase of $\mathrm{Li}_{x} \mathrm{Sn}$ alloys. However, the cycle life for these tin alloys is still poor, preventing any practical application. Silicon has a high theoretical lithium storage capacity of $4000 \mathrm{mAh} / \mathrm{g}$ when forming $\mathrm{Li}_{21} \mathrm{Si}_{5}$ alloys. Wilson and Dahn ${ }^{15}$ have synthesized nanodispersed silicon in carbon using chemical vapor deposition (CVD). Although the Si-C anodes demonstrated a reversible capacity of $500 \mathrm{mAh} / \mathrm{g}$, it is difficult to control the morphology of Si and C using the CVD approach. Niu and Lee ${ }^{16}$ dispersed crystalline silicon (325 mesh) in a sol-gel graphite matrix by ballmilling and achieved a reversible capacity of $832.2 \mathrm{mAh} / \mathrm{g}$ in the first cycle. Nano-Si-carbon composites have been prepared by hand mixing nano-Si and carbon black, which demonstrated a high reversible capacity of $1700 \mathrm{mAh} / \mathrm{g} .{ }^{17}$ The lithium storage properties of nanostructured $\mathrm{Si}$ and $\mathrm{Si}$ film have also been investigated. ${ }^{18,19}$

Since MCMB anode materials have the best cyclability among all the various types of carbon anode materials, the combination of MCMB and Si may result in Si-MCMB composite anode materials with high capacity and satisfactory rechargeability. Based on this hypothesis, we prepared nanocrystalline Si-MCMB composite materials by high-energy ballmilling. Their electrochemical properties as anodes in lithium-ion cells were systematically evaluated.

\section{Experimental}

Nanocrystalline $\mathrm{Si}$ with an average particle size of $80 \mathrm{~nm}$ was obtained from Nanostructured \& Amorphous Materials Inc., USA, which were prepared by laser driven silane gas reaction. MCMB (MCMB-10 graphitizing) was supplied by Osaka Gas Co. (Japan). MCMB powders have an average particle size of $10 \mu \mathrm{m}$. Nanocrys-

\footnotetext{
* Electrochemical Society Active Member

zz-mail: gwang@uow.edu.au
}

talline Si-MCMB composites were prepared by high-energy ballmilling using a planetary ballmilling machine (Labtechnics, Australia). The nanocrystalline Si content in the composite is $20 \mathrm{wt} \%$. We chose this percentage based on the results of a previous investigation on ballmilled Sn-graphite ${ }^{20}$ and ballmilled Si-graphite. ${ }^{21}$ The mixtures were ballmilled for 5,10 , and $20 \mathrm{~h}$, respectively, to obtain three batches of Si-MCMB composites. The as-prepared Si-MCMB composites were characterized by scanning electron microscopy (SEM, Leica/Cambridge Stereoscan 440 scanning electron microscope) and X-ray diffraction (XRD) with $\mathrm{Cu} \mathrm{K} \alpha$ radiation (MO3xHF22, MacScience, Japan).

The electrochemical properties of Si-MCMB composites were measured via coin cell testing. The Si-MCMB electrodes were made by dispersing $84 \mathrm{wt} \%$ active materials, $8 \mathrm{wt} \%$ carbon black, and 8 wt $\%$ polyvinylidene fluoride (PVDF) binder in dimethyl phthalate solvent to form a homogeneous slurry. The slurry was spread onto a copper foil. The coated electrodes were dried in a vacuum oven at $120^{\circ} \mathrm{C}$ for $12 \mathrm{~h}$ and then pressed to enhance the contact between the active materials and the conductive carbons. The CR2032 coin cells were assembled in an argon-filled glove box (Mbraun, Unilab, Germany) using lithium metal foil as the counter electrode. The electrolyte was $1 \mathrm{M} \mathrm{LiPF}_{6}$ in a mixture of ethylene carbonate (EC) and dimethyl carbonate (DMC) (1:1 by volume, provided by Merck KgaA, Germany). The cells were galvanostatically discharged and charged in the range of $0.01-3 \mathrm{~V}$ at a current density of $0.05 \mathrm{~mA} / \mathrm{cm}^{2}$. Cyclic voltammetry $(\mathrm{CV})$ was performed on a potentiostat (model M362, EG\&G Princeton Applied Research, USA) at a scanning rate of $0.1 \mathrm{mV} / \mathrm{s}$.

\section{Results and Discussion}

MCMB particles have a spherical shape. Figure 1a shows an SEM photo of MCMB particles, which consists of many small

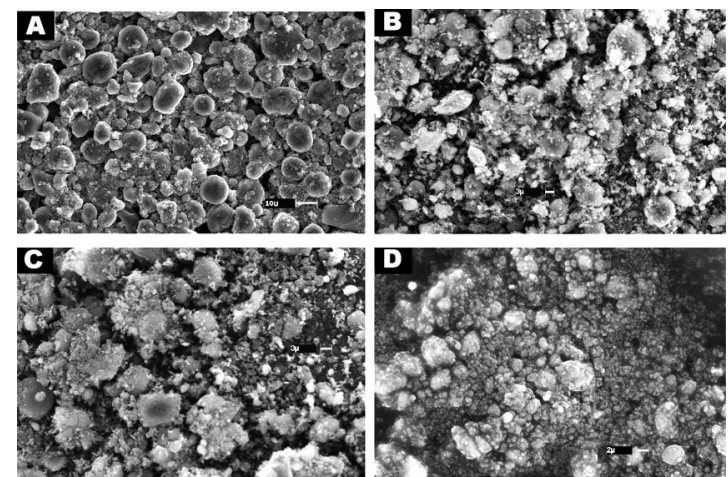

Figure 1. SEM image of (a) bare MCMB graphite, (b) 20 wt \% nano $\mathrm{Si}$ MCMB ballmilled for $5 \mathrm{~h}$, (c) 20 wt \% nano-Si-MCMB ballmilled for $10 \mathrm{~h}$, and (d) $20 \mathrm{wt} \%$ nano-Si-MCMB ballmilled for $20 \mathrm{~h}$. 


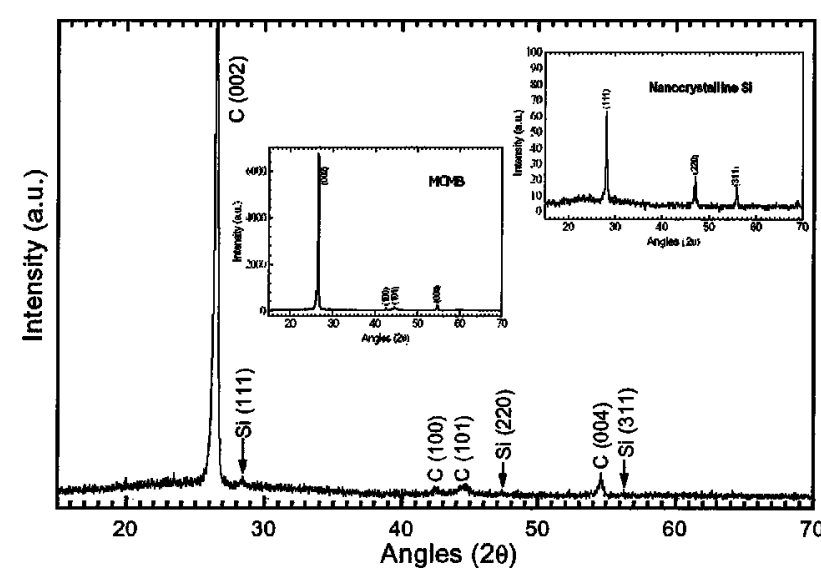

Figure 2. XRD pattern of $20 \mathrm{wt} \%$ nano-Si-MCMB ballmilled for $10 \mathrm{~h}$.

graphite particles. The images of the Si-MCMB composites ballmilled for different times are shown in Fig. 1b, c, and d. After ballmilling for 5 and $10 \mathrm{~h}$, the spherical agglomerates were partially broken. But most particles still retained a spherical shape. However, after $20 \mathrm{~h}$ extensive ballmilling, most spherical MCMB agglomerates were destroyed and formed finely ground graphite debris. Energy-dispersive spectrometry (EDS) detection was performed on the bulk of Si-MCMB composites and confirmed the presence of $\mathrm{Si}$. Figure 2 shows the XRD pattern of Si-MCMB. As a comparison, the XRD patterns of bare MCMB and nanocrystalline Si are also presented in the inset. The intensities of the diffraction lines of nanocrystalline $\mathrm{Si}$ are much weaker than for MCMB graphite, indicating the nanocrystalline nature of $\mathrm{Si}$. The ballmilling process caused slight broadening of the (002) peak of MCMB graphite. The full
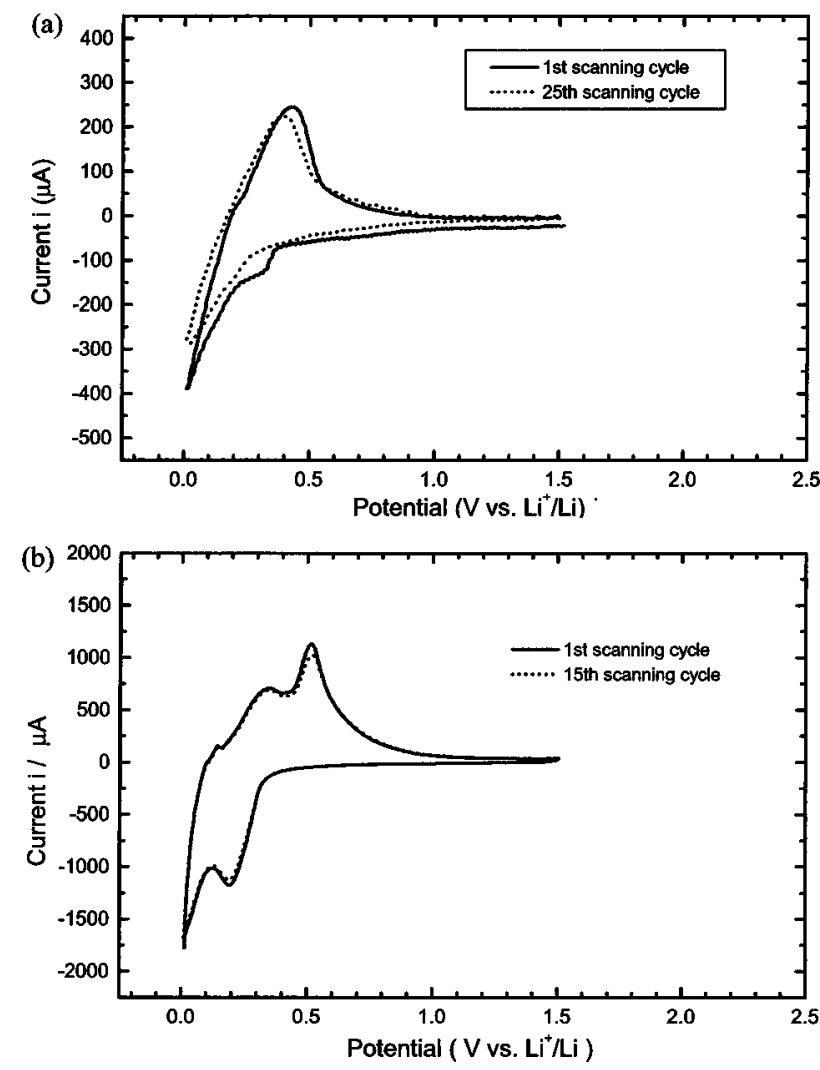

Figure 3. CVs of (a) MCMB electrode and (b) nano-Si-MCMB electrode (sample E).

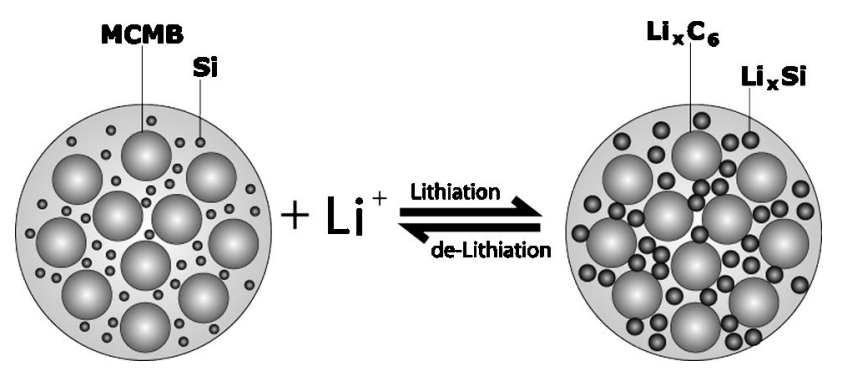

Figure 4. Schematic model of the lithiation and delithiation process in SiMCMB composites. The volume increases due to the formation of $\mathrm{Li}_{x} \mathrm{Si}$ alloys are small in local domain and effectively buffered by MCMB matrix.

width at half-maximum (fwhm) of (002) diffraction peak of MCMB were calculated to be $0.248,0.250,0.278$, and $0.296^{\circ}$ for pristine MCMB and $5 \mathrm{~h}$ ballmilled Si-MCMB, $10 \mathrm{~h}$ ballmilled Si-MCMB, and $20 \mathrm{~h}$ ballmilled Si-MCMB, respectively. No SiC phase was detected by XRD. Therefore, the mechanically added nanocrystalline $\mathrm{Si}$ forms $\mathrm{Si}-\mathrm{MCMB}$ composites.

Cyclic voltammograms (CVs) of MCMB and Si-MCMB electrodes in lithium-ion cells, in which a lithium foil was used as the counter electrode and reference electrode, are shown in Fig. 3a and b, respectively. In Fig. 3a, the potential of the lithium ion insertion peak in the cyclic voltammetric curve of MCMB electrode is very close to $0.0 \mathrm{~V} v s$. the $\mathrm{Li} / \mathrm{Li}^{+}$reference electrode, whereas the potential of lithium extraction is in the range $0.3-0.4 \mathrm{~V}$ vs. the $\mathrm{Li} / \mathrm{Li}^{+}$ reference electrode. In Fig. 3b, one pair of additional reduction and oxidation peaks appeared in the CV curve of the Si-MCMB electrode, which is located at around 0.2 and $0.51 \mathrm{~V}$ vs. the $\mathrm{Li} / \mathrm{Li}^{+}$ reference electrode. This pair of redox peaks should correspond to
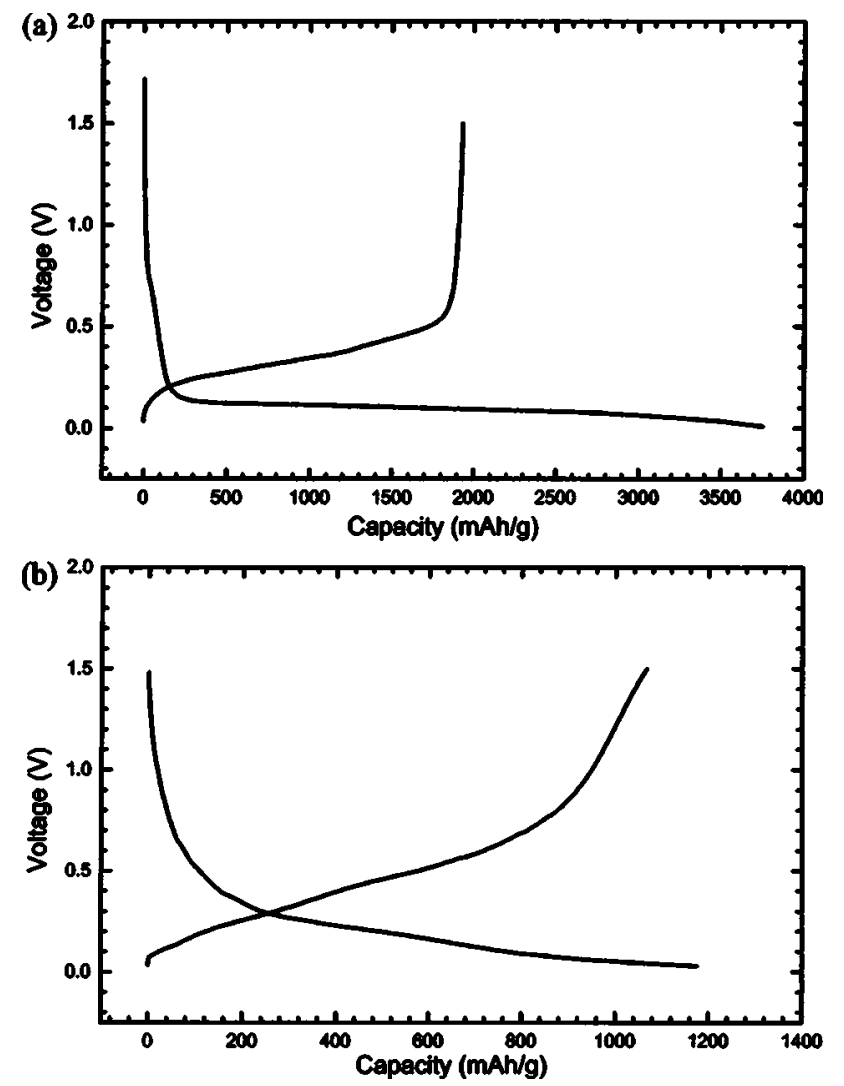

Figure 5. The discharge/charge profiles of (a) bare nano-Si electrode and (b) nano-Si-MCMB electrode (sample E). 


\begin{tabular}{|c|c|c|c|c|}
\hline Samples & $\underset{(\mathrm{mAh} / \mathrm{g})}{Q_{\text {discharge }}}$ & $\underset{(\mathrm{mAh} / \mathrm{g})}{Q_{\text {charge }}}$ & $\underset{(\mathrm{mAh} / \mathrm{g})}{Q_{\text {irreversible }}}$ & $\begin{array}{l}\text { Efficiency } \\
\quad(\%)\end{array}$ \\
\hline Sample A (bare MCMB) & 355 & 325 & 25 & 91.5 \\
\hline Sample B (bare nanocrystalline $\mathrm{Si}$ ) & 3752 & 1931 & 1821 & 51.5 \\
\hline $\begin{array}{l}\text { Sample C }(20 \text { wt } \% \mathrm{Si}(2 \mu \mathrm{m})+\mathrm{MCMB} \text {, ballmilled } \\
\text { for } 10 \mathrm{~h})\end{array}$ & 687 & 382 & 305 & 55.6 \\
\hline $\begin{array}{l}\text { Sample D ( } 20 \mathrm{wt} \% \mathrm{Si} \text { (nanocrystalline) }+ \\
\text { MCMB, ballmilled for } 5 \mathrm{~h} \text { ) }\end{array}$ & 1105 & 936 & 239 & 84.7 \\
\hline $\begin{array}{l}\text { Sample E }(20 \mathrm{wt} \% \mathrm{Si} \text { (nanocrystalline) }+ \\
\text { MCMB, ballmilled for } 10 \mathrm{~h})\end{array}$ & 1175 & 1066 & 115 & 90.7 \\
\hline $\begin{array}{l}\text { Sample F ( } 20 \mathrm{wt} \% \mathrm{Si} \text { (nanocrystalline) }+ \\
\text { MCMB, ballmilled for } 20 \mathrm{~h})\end{array}$ & 1273 & 1012 & 261 & 79.5 \\
\hline
\end{tabular}

the lithiation and delithiation of $\mathrm{Si}$ in the MCMB matrix. The results of CV measurements clearly demonstrated that Si participated in the reaction with lithium ions.

The specific capacity and cyclability of nanocrystalline SiMCMB composite electrodes were measured by constant current charge/discharge testing. Table I shows the discharge and charge capacities in the first cycle for different sample electrodes. The bare MCMB electrode (sample A) delivered a reversible capacity of 325 $\mathrm{mAh} / \mathrm{g}$ in the first cycle with high efficiency. The bare nanocrystalline Si electrode (sample B) delivered a very high lithium storage capacity of $3752 \mathrm{mAh} / \mathrm{g}$, which is very close to its theoretical capacity of $4000 \mathrm{mAh} / \mathrm{g}$. However, this nanocrystalline Si anode had a very high irreversible capacity of about $1821 \mathrm{mAh} / \mathrm{g}$ in the first cycle. The formation of $\mathrm{Li}_{4.2} \mathrm{Si}$ alloys induces a $323 \%$ volume increase. ${ }^{4}$ Such high volume increase could create microcracks and therefore destroy the integrity of the electrode, causing high irreversible capacity and poor cyclability. Sample C is crystalline $\mathrm{Si}(2$ $\mu \mathrm{m})$-MCMB composite prepared by ballmilling for $10 \mathrm{~h}$. Sample C anode shows a lower specific capacity and poorer rechargeability than for nanocrystalline Si-MCMB electrodes (samples D, E, and F). The chemical reactivity of coarse crystalline $\mathrm{Si}$ is much lower than that of nanocrystalline Si. Correspondingly, the contribution to lithium storage capacity from $\mathrm{Si}$ is smaller. Because of the effect of the coarse particle size, the volume change in local domains in sample $\mathrm{C}$ anode may be much larger than for nanocrystalline $\mathrm{Si}$ when embedded in MCMB. Therefore, sample $\mathrm{C}$ demonstrates lower specific capacity and higher irreversible capacity on cycling.

The ballmilling time had a significant impact on the specific capacity and rechargeability of Si-MCMB composite anodes.

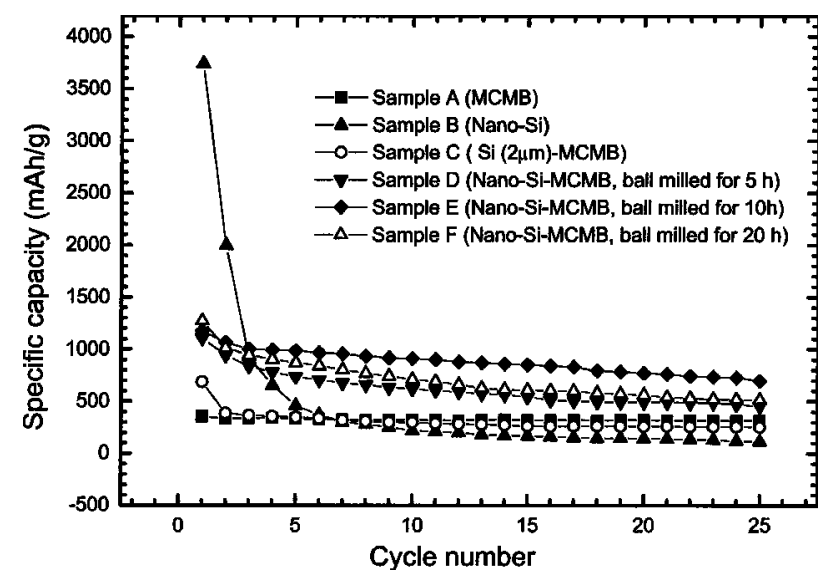

Figure 6. The discharge capacity vs. cycle number. Current density $0.05 \mathrm{~mA} \mathrm{~cm}^{-2}$
Sample E (ballmilled for $10 \mathrm{~h}$ ) showed an optimal lithium storage capacity and capacity retention on cycling. We intended to use the ballmilling process to disperse nanocrystalline $\mathrm{Si}$ in MCMB matrix. The longer the ballmilling time, the better the dispersing effect that is obtained. However, ballmilling inevitably breaks up the MCMB spherical particles and destroys the graphite structure, therefore degrading the electrochemical properties of MCMB electrodes. Longtime ballmilling induces high surface area of MCMB powders. The irreversible capacity in the first cycle is considered coming from the formation of a passivating film, which consumes lithium at the electrode materials/electrolyte interface. ${ }^{21-23}$ From SEM observation, we found that the spherical MCMB particles were severely damaged after $20 \mathrm{~h}$ ballmilling. Therefore, the sample F (ballmilled for $20 \mathrm{~h}$ ) anode exhibited a very high irreversible capacity. To achieve better electrochemical performance for nanocrystalline Si-MCMB anodes, Si must be dispersed homogeneously in the MCMB matrix without damaging the spherical MCMB structure. Sample E seems to meet this requirement.

To combat the problems caused by volume increase in the alloying process, reducing the particle size of $\mathrm{Si}$ is an efficient way to minimize the volume change in local domains due to the formation of $\mathrm{Li}_{x} \mathrm{Si}$ alloys. Another approach to overcome this issue is to embed the active element in an inactive matrix to let the inactive matrix absorb or buffer the volume expansion. The intermetallic $\mathrm{MM}^{\prime}$ alloys and tin composite oxides (TCO) are exactly designed to utilize this principle. We embedded nanocrystalline $\mathrm{Si}$ particles in an MCMB matrix through moderate ballmilling. When lithium ions are inserted into Si-MCMB composites, nano-Si reacts with $\mathrm{Li}$ to form $\mathrm{Li}_{x} \mathrm{Si}$ alloys and MCMB graphite reacts with $\mathrm{Li}$ to form $\mathrm{Li}_{x} \mathrm{C}_{6}$. The intercalation of $\mathrm{Li}$ in MCMB graphite causes only minor changes of interlayer spacing and stacking order. MCMB graphite is almost dimensionally invariable during lithium insertion and extraction. ${ }^{24}$ Because Si particles are nanosize in nature, the volume increase in the local environment is small, and can be easily absorbed by the ductile MCMB graphite matrix surrounded around nano-Si clusters. As a result, the volume change in the macrodomain is small and negligible for Si-MCMB electrodes. During the lithium extraction process, a similar phenomena occurs. This allows the integrity of the electrode to be preserved for repeated lithium insertion and extraction. A schematic model of the lithiation and delithiation process in $\mathrm{Si}$-MCMB composite was proposed and presented in Fig. 4.

Figure 5 shows the discharge/charge profiles in the first cycle for bare nanocrystalline $\mathrm{Si}$ (sample B) and nano-Si-MCMB (sample E) anodes. The nanocrystalline Si electrode shows a flat discharge plateau between 0.2 and $0.05 \mathrm{~V}$, corresponding to the reduction peak in the CV curve (Fig. 3b), indicating the highly reactive nature of nanocrystalline $\mathrm{Si}$ powders. In contrast, the Si-MCMB (sample E) anode shows a parabolic curve between 0.5 and $0.2 \mathrm{~V}$ and a flat plateau between 0.1 and $0.0 \mathrm{~V}$, which is typical for composite electrode materials. The cyclabilities of all the sample anodes are shown 
in Fig. 6. The bare MCMB anode is very stable on cycling, but with limited capacity. Although the bare nanocrystalline Si anode (sample B) has a high initial capacity, its capacity decreased quickly on cycling. Therefore, it is not suitable to use nanocrystalline Si alone as an electrode in Li-ion cells. Generally, nanocrystalline $\mathrm{Si}-\mathrm{MCMB}$ composite electrodes demonstrated superior performance (high capacity and satisfactory cyclability), compared to bare MCMB and bare nano-Si electrodes. In particular, sample E shows stable cyclability similar to the bare MCMB electrode, but with much higher capacity. We believe that the electrochemical performance of nanoSi-MCMB composites may be further optimized through tuning the material processing.

\section{Conclusions}

Nanocrystalline Si-MCMB composite anode materials were prepared by ballmilling. They are intended to utilize the high capacity of $\mathrm{Si}$ and the stable cyclability of MCMB. The CV measurements show that $\mathrm{Si}$ participates in the reaction with lithium in $\mathrm{Li}$-ion cells. In this investigation, we achieved a reversible capacity of 1066 $\mathrm{mAh} / \mathrm{g}$ for nanocrystalline Si-MCMB composites and fairly good cyclability. A reaction model was proposed for the lithiation and delithiation process in the Si-MCMB electrodes in lithium-ion cells.

\section{Acknowledgments}

The authors express their thanks for financial support from the Australia Research Council through ARC Linkage project (LP0219309) with industry partner, Sons of Gwalia Ltd. We thank Professor J. Y. Lee for fruitful discussion.

The University of Wollongong assisted in meeting the publication costs of this article.

\section{References}

1. D. Guymard and J. M. Tarascon, J. Electrochem. Soc., 139, 937 (1992)

2. K. Sato, M. Noguchi, A. Demachi, N. Oki, and M. Endo, Science, 264, 556 (1994).

3. J. R. Dahn, T. Zheng, Y. H. Liu, and J. S. Xue, Science, 270, 590 (1995).

4. M. Winter and J. O. Besenhard, Electrochim. Acta, 45, 31 (1999).

5. D. Fauteux, J. Appl. Electrochem., 23, 1 (1993).

6. K. D. Kepler, J. T. Vaughey, and M. M. Thackeray, Electrochem. Solid-State Lett. 2, 307 (1999).

7. G. X. Wang, L. Sun, D. H. Bradhurst, S. X. Dou, and H. K. Liu, J. Alloys Compd., 147, 3237 (2000)

8. L. Y. Beaulieu and J. R. Dahn, J. Electrochem. Soc., 147, 3237 (2000).

9. O. Mao, R. L. Turner, L. A. Courtney, B. D. Fredericksen, M. J. Buckett, L. J. Krause, and J. R. Dahn, Electrochem. Solid-State Lett., 2, 3 (1999).

10. O. Mao, R. A. Dunlap, and J. R. Dahn, J. Electrochem. Soc., 146, 405 (1999).

11. O. Mao and J. R. Dahn, J. Electrochem. Soc., 146, 414 (1999).

12. J.-H. Ahn, G. X. Wang, M. J. Lindsay, S. X. Dou, and H. K. Liu, J. Metastable Nanocryst. Mater., 10, 595 (2001).

13. Y. Idota, U.S. Pat. $5,478,671$ (1995)

14. Y. Idota, T. Kubota, A. Matsufuji, Y. Maekawa, and T. Miyasaka, Science, 276, 1395 (1997).

15. A. M. Wilson and J. R. Dahn, J. Electrochem. Soc., 142, 326 (1995).

16. J. Niu and J. Y. Lee, Electrochem. Solid-State Lett., 5, A107 (2002).

17. H. Li, X. J. Huang, L. Q. Chen, Z. G. Wu, and Y. Liang, Electrochem. Solid-State Lett., 2, 547 (1999).

18. J. Graez, C. C. Ahn, R. Yazami, and B. Fultz, Electrochem. Solid-State Lett., 6 , A194 (2003).

19. S. Ohara, J. Suzuki, K. Sekine, and T. Takamura, J. Power Sources, 119-121, 591 (2003).

20. G. X. Wang, M. J. Lindsay, L. Sun, D. H. Bradhurst, S. X. Dou, and H. K. Liu, J. Power Sources, 97-98, 211 (2001).

21. C. S. Wang, G. T. Wu, X. B. Zhang, Z. F. Qi, and W. Z. Li, J. Electrochem. Soc., 145, 2751 (1998)

22. F. Disma, L. Aymard, L. Dupont, and J.-M. Tarascon, J. Electrochem. Soc., 143 3959 (1996).

23. F. Disma, C. Lenain, B. Beaudoin, L. Aymard, and J.-M. Tarascon, Solid State Ionics, 98, 145 (1997).

24. J. O. Besenhard, J. Yang, and M. Winter, J. Power Sources, 68, 87 (1997). 